brazilianpoliticalsciencereview

ART I CLE

\title{
Does Size Matter?
}

\section{Electoral Performance of Small Parties in Brazil ${ }^{*}$}

\author{
Willber Nascimento \\ Universidade Federal de Pernambuco, Brazil \\ José Alexandre dla Sillva Jr. \\ Universidade Federal de Alagoas, Brazil \\ Ranulfo Paranhos \\ Universidade Federal de Pernambuco, Brazil \\ Denisson Silva \\ Universidade Federal de Alagoas, Brazil \\ Dalson Britto Figueiredo Fillho \\ Universidade Federal de Pernambuco, Brazil
}

\begin{abstract}
What is the impact of small parties on electoral outcomes? This articles aims at contributing to the literature on party systems by proposing a new method to classify political parties. The methodology is applied to Brazil by focusing on the description of the election results of small parties. Cluster analysis is employed to classify political party size based on their percentage of votes in the Brazilian states. The main findings indicate that classifying parties through cluster analysis is more objective than previous classifications. As a result of this method, the article shows that small parties exert little effect on electoral volatility in Brazil as well as small parties benefit less from the disproportionality between votes and seats than the larger ones.
\end{abstract}

Keywords: Small parties; cluster analysis; electoral volatility; disproportionality.

For data replication, see bpsr.org.br/files/archives/Dataset_Nascimento. 
$\mathrm{F}$

or the average voter, small parties (from now on, SPs) are electorally weak, do not field strong candidates (vote pullers) and have no real chance of victory. Nonetheless, small parties are often cited by the specialized literature. In Brazil, these parties are seen as a bad influence and partly responsible for both high levels of volatility and fragmentation. Moreover, SPs are usually labelled as parasites of the Brazilian political system. The widespread belief is that these parties depend on the help of larger parties in coalitions: without the larger parties it would be impossible for the smaller ones to obtain seats in parliament. Despite these negative attributes, SPs have seldom been subject to specific analyses. The literature that do take into account party size typically forget to examine the impact of SPs on election results in any systematic way.

What is the real impact of small parties on election results? This article sets out to answer this question. Our analysis draws from data published by the Superior Electoral Court (Tribunal Superior Eleitoral: TSE${ }^{1}$ ) referring to federal deputy elections from 1998 to 2014. More precisely, we propose a new classification of parties through cluster analysis. We employ electoral support for parties to calculate their size more accurately. In addition, we used both descriptive and multivariate statistics to estimate the effect of small parties on electoral outcomes, particularly in relation to volatility and proportionality.

The remainder of this article is divided into four main sections. First, we present the main predictions and findings of the literature. Next, we define the methodological procedures for achieving the two main aims of this article: 1) classifying parties, and 2) identifying the effect of SPs on election results. The third section describes the main findings. The last section presents our conclusions.

\section{Small parties in Brazil}

As in so many other cases, the debate on Brazilian SPs has both a theoretical and an empirical dimension. The former is more developed than the latter. The concern with SPs became more intense with Brazil's return to democracy in the 1980s. The political openness enabled the creation of parties based on rules considered fairly lax. During this period, specialists and the lay

\footnotetext{
${ }^{1}$ See www.tse.jus.br.
} 
public began to worry about the negative effects of a potential avalanche of new parties (ALMEIDA, 2007; MARCHETTI, 2008; RABAT, 2012). On one hand, an overwhelming increase in party fragmentation was anticipated, along with the negative impacts of this phenomenon on governability (ASSIS, 1997; MELO, 2010, 2011; MELO and CÂMARA, 2012; RODRIGUES, 1995). On the other, a decline in party identification was expected, matched by an increase in electoral volatility. Hence, the expectations concerning the creation of new parties were for a double negative effect. The first would hit the legislative arena, the second the electoral.

According to Kinzo (2004), the Brazilian party system became one of the most fragmented in the world. For many, the party fragmentation hinders the creation and/or maintenance of a viable legislative base to support the government (KINZO, 2004; MAINWARING, 1999; MENEGUELO, 1998; NOVAES, 1996; RODRIGUES, 1995). A large part of this problem is blamed on the ease with which political parties can be created in Brazil. Consequently, the so-called dwarf or small parties are held directly responsible (ROGRIGUES, 1995).

At the very least, this context indicates the need to adopt a ceiling for the participation of SPs in the legislative arena. Commentators emphasize the importance of a performance clause with a double function: 1) to curb the creation of new parties, and 2) to reduce the chances of SPs obtaining legislative representation (MARCHETTI, 2008; RABAT, 2012).

In the electoral arena, Peres et al. (2011) argue that the excessive number of parties increases electoral volatility. The emergence of new parties is another obstacle to party fidelity. More precisely, the profusion of political parties tends to confuse the electoral market and the mind of the voter (BOHN and PAIVA, 2009; FEREJOHN, 1999; KINZO, 2004; KRAUSE et al., 2013). Consequently, the parties lose their brand-like property and volatility tends to rise (MAINWARING and TORCAL, 2005). Some scholars argue that SPs contribute decisively to this situation, especially since they are created and recreated apparently at whim - that is, with very little or no ideological content (MAINWARING, 1999).

In this case, the lack of definition in electoral contests is partly attributed to the creation of parties, more specifically, small parties. Furthermore, SPs are considered active agents in the electoral market. According to Machado (2005), they barter their support with large parties in the main electoral contest in 
exchange for support in the others. Hence, the SPs influence the structuring of the contests even when they do not put up candidates (MACHADO, 2012). In short, there are theoretical reasons for expecting a negative effect from the profusion of parties in the electoral arena. In particular, SPs are expected to reduce party identification and increase electoral volatility.

Most of the studies cited so far lack an empirical basis for classifying the parties. In fact, few works establish any criterion for measuring party size in Brazil. The main texts to do so are Assis (1997), Dantas and Praça (2004, 2010), Machado (2005, 2012), Melo and Ev (2014) and Rodrigues (1995).

Dantas and Praça $(2004,2010)$ represent the most sustained effort to map the electoral results of small parties in Brazil. The earlier work involves the attempt to define or classify what a SP is, while the later analyses the electoral coalitions in which they participate, as well as the ideological consistency of these coalitions. In both cases, the classificatory parameter is the performance of parties in elections to the Chamber of Deputies.

Assis (1997) and Rodrigues (1995) seek out evidence of the negative effect of SPs on the political system. Both authors see them as irrelevant structures that hinder governability and serve merely the personal interests of their leaders. Again, both Assis (1997) and Rodrigues (1995) use the electoral performance of parties in the dispute for a seat in the Chamber of Deputies as a classificatory parameter.

Dantas and Praça (2004) investigate the hypothesis widespread in the literature that small parties look for 'shelter' in the larger parties as the elections approach. According to the authors, $85 \%$ of the coalitions realized by SPs include large parties. Moreover, they point to a considerable ideological consistency among the alliances made by SPs. In $74 \%$ of the coalitions formed, the right-wing SPs were allied with large parties sharing a similar ideological stance. Likewise, the left-wing SPs forged alliances with large left-wing parties. Finally, Dantas and Praça (2010) report that the SPs are widening their bases, or at least are fighting elections in more municipalities. Additionally, the participation of these parties in coalitions increased across Brazil (DANTAS and PRAÇA, 2010).

Machado (2012) suggests that small parties depend on large parties to build their coalitions. She establishes a direct and positive relation between elections for state government and coalitions in the contests for the Chamber of 
Deputies. Machado (2012) goes on to argue that large parties help the smaller parties to build coalitions for the latter house. In exchange, the small parties refrain from disputing the state government elections and ally themselves with larger parties, offering their support (including during the free election broadcast slots on TV and radio).

Again according to Machado (2012), the SPs are the most dependent on coalitions. According to her, it is practically impossible for the dwarf parties to win seats in the legislature without this strategy. Since the situation is even worse in majoritarian elections, the small parties owe their political survival to the coalitions (MACHADO, 2012). Obviously, this 'crutch' will be more efficient the more SPs manage to gain advantages through the alliances (DANTAS and PRAÇA, 2004, 2010; MACHADO, 2012). One of the outcomes of this strategy is the increased distortion in the distribution of seats according to party electoral performance.

Melo and Ev (2014) contribute substantially to the work of mapping the electoral space of the SPs. Their analysis focuses on the seats won by these parties in the Chamber of Deputies, the number of mayors elected, and the territorial distribution of their votes. Concluding their study, the authors point to the electoral growth of some parties and a relation between this upward trend and their degree of territorial grassroots development. They also show that successful SPs (those winning seats and/or mayorships) tend to maintain their electoral performance.

In sum, two general trends can be identified in the literature. The first concerns the strategic participation of SPs in coalitions. Their political survival is linked to how they negotiate their alliances. At the same time, the literature indicates a significant growth in electoral support for small parties, both in terms of number of votes and in terms of seats won (DANTAS and PRAÇA, 2004, 2010; MELO and EV, 2014). It seems that SPs have been gaining influence and spreading across Brazil as a whole.

The theoretical dimension of the debate points to the impacts in the legislative and electoral arena. At the legislative level, SPs are expected to increase fragmentation and hamper governability. At the electoral level, the expectation is for an increase in volatility and disproportionality. In this work, we investigate just 
the effect on electoral results. In other words, we want to estimate the effect of SPs on electoral volatility and the distribution of seats by party.

\section{Methodology}

The first challenge is to calculate the size of parties, precisely in order to distinguish the small parties from the rest. Next, our aim is to estimate the difference that these parties make to the results of elections, more specifically in relation to volatility and proportionality.

\section{The size of parties}

Estimating the size of parties has been seen as a tricky problem by the literature (DANTAS and PRAÇA, 2004, 2010; MELO and EV, 2014). Generally speaking, one of two procedures are adopted: 1) the attribution of fixed intervals (ASSIS, 1997; DANTAS and PRAÇA, 2004, 2010; MACHADO, 2012; RODRIGUES, 1995) or 2) the total lack of definition (ALMEIDA, 2007; CARREIRÃO, 2006, 2012; FIGUEIREDO and LIMONGI, 1995; FLEISHER, 2007; KINZO, 2004; LIMONGI and CORTEZ, 2010; MELO, 2010; NICOLAU, 2006; PERES et al., 2011).

Table 01. Size of small parties

\begin{tabular}{llr}
\hline Text & Main Parameter & Interval \\
\hline Rodrigues (1995) & Number of seats - Chamber of Deputies & $11-30$ \\
Dantas and Praça (2004, 2010) & Percentage of votes - Chamber of Deputies & $0-01$ \\
Assis (1997) & Percentage of votes - Chamber of Deputies & $3.1-05$ \\
Machado (2012) & Percentage of votes - Chamber of Deputies & $1.1-10$ \\
Melo and Ev (2014) & Percentage of votes - Chamber of Deputies & $0-2.5$ \\
\hline
\end{tabular}

Dantas and Praça (2004) and Melo and Ev (2014) admit that it is impossible to find a standard definition of political parties that includes them. According to these authors, the simplest way of characterizing SPs is to analyse electoral support. This is because all parties compete in the electoral market for citizens' votes and try to formulate policies that maximize their chances of promoting specific interests (DOWNS, 1999; SCHUMPETER, 1952). Taking electoral support as a parameter does not resolve the question, though. After all, how much support does a party need to be deemed small? Unless we are mistaken, 
all the works that sketch out a reply to this question establish theoretically-based intervals. Table 01 above summarizes the efforts made in this direction.

Four of the five works use percentage of votes received by parties. The one exception opts for the number of seats won. No coincidence is evident between the limits established in these texts. In other words, parties considered small in one classification are not considered so in another. There is no way for us to judge which is the best classification if we stick exclusively to the theoretical discussion. Hence, our own classification will be based on technical grounds. The most suitable classification is one that unites the most similar cases and separates the most different (HAIR et al., 2009). In other words, classifications that form groups with high levels of internal homogeneity and high external heterogeneity (between groups) (GUGIU and CENTELLAS, 2013; HAIR et al., 2009). In addition, we build a relational classification, as suggested by Dantas and Praça (2004), not setting fixed intervals to define which parties will be in each group in all elections, in all federal units. These bands vary according to the size of parties in any given context. The logic is simple: someone $1.70 \mathrm{~m}$ in height may be considered small among the US basketball league (NBA) but undoubtedly will not be deemed short among a population of pygmies.

To meet this challenge, we employed cluster analysis. This technique enables objects to be grouped on the basis of one or more particular characteristics. Hair et al. (2009) argue that, from the ideal point of view, cluster analysis is suited to creating case groups with maximum homogeneity within the same group and maximum heterogeneity between the formed groups. Hence, we define the groups based on the distance between the percentage of votes that each party obtained in each federal unit.

\section{The effect of the small parties}

According to the suggestions found in the literature, SPs exert an effect on two elements of electoral results: 1) electoral volatility and 2) proportionality. Firstly, then, our aim is to verify whether the small parties exert any significant effect on electoral volatility. To this end, we used two methodological strategies: 1) the comparison between the mean electoral volatility of the federal units with higher or lower number of small parties, and 2) an analysis of the correlation 
between general volatility (generated by all parties) and the specific volatility of the SPs. With the first strategy our aim is to investigate whether the choice of parties has an effect on volatility. With the second we aim to identify the effect of the volatility generated by the SPs on overall volatility.

Table 02. Summary of methodology

\begin{tabular}{|c|c|c|}
\hline Stage & Elements & Description \\
\hline \multirow{4}{*}{$\begin{array}{l}\text { Classification } \\
\text { of the Parties }\end{array}$} & $\begin{array}{l}\text { Unit of } \\
\text { Analysis }\end{array}$ & Party $\mathrm{x}$, in FU $\mathrm{y}$, in election $\mathrm{z}$ \\
\hline & Elections* & 1998 to 2014 (election for Chamber of Deputies) \\
\hline & Variables & $\begin{array}{l}\text { Percentage of votes of the political parties (nominal } \\
\text { votes + party votes) in the FU }\end{array}$ \\
\hline & Techniques & $\begin{array}{l}\text { Cluster analysis; Measure of similarity: log-likelihood; } \\
\text { Cluster method: TwoStep Cluster. Number of } \\
\text { categories: determined spontaneously by the software }\end{array}$ \\
\hline \multirow{4}{*}{$\begin{array}{l}\text { Estimation of } \\
\text { Effect }\end{array}$} & $\begin{array}{l}\text { Unit of } \\
\text { Analysis }\end{array}$ & Party $x$, in FU $y$, in election $z$ \\
\hline & Elections & 1998 to 2014 (election for Chamber of Deputies) \\
\hline & Variables & $\begin{array}{l}\text { Electoral volatility (all parties); Electoral volatility } \\
\text { (SP); Disproportionality; Electoral quotient; Seats won }\end{array}$ \\
\hline & Techniques & $\begin{array}{l}\text { T-test for comparison of means; analysis of } \\
\text { correlation; analysis of variation and x2 test of } \\
\text { association }\end{array}$ \\
\hline
\end{tabular}

Note: $(*)$ The Supreme Electoral Court's data repository for the elections of 1990 and 1994 does not contain data for the Brazilian states corresponding to all variables used here. These years were omitted from the analysis.

Table 2 summarizes our methodology. On the question of proportionality, the aim is to ascertain whether the SPs contribute significantly to distorting the conversion of party electoral performance into seats won. For this purpose, we adopted two strategies: 1) an analysis of the association between exceeding the electoral quota and winning seats, and 2) a comparison of the mean disproportionality between groups of parties of different sizes. More precisely, the strategy aims to verify whether the SPs benefit from coalition politics. In the former case, they would receive seats even without attaining the electoral quota, meaning that they would contribute to increased distortion. In the latter case, the objective is to verify whether the SPs benefit more from disproportionality than other parties. 


\section{Results}

This section is divided into two parts. In the first we present the results of our classification, compare them with the others, and present the electoral performance of the small parties. In the second we test the working hypotheses concerning the effects of small parties on electoral volatility and proportionality.

The first step in identifying the effect of SPs on electoral results is to measure the size of political parties - or, rather, distinguish the SPs from the others. To this end, we need to create groups with the most similar cases and distinguish those groups through the difference between cases. We therefore grouped the parties according to the percentage of votes won in the Brazilian states via cluster analysis. This procedure takes into account the variation in state party subsystems, as indicated by Lima Jr. (1983) ${ }^{2}$. Hence, the size of the party varies according to the context of state party competition. Our classification indicated the formation of three groups of parties of different sizes (small, medium and large). In some states, however, the solution indicates just two groups of parties that we define as small and large. Table 03 summarizes the frequency of party size by states and the Federal District.

From 1998 to 2014, among the states with three groups of parties, Roraima presented the highest incidence of small parties competing (79.17\%), followed by Goiás (74.79\%). On the other hand, among the federal units with two groups of parties, Bahia and Ceará presented the highest percentages of SPs (89.47\%), followed by the Federal District (88.89\%) and Mato Grosso do Sul $(88,46 \%)$. In order to assess this methodology, we compared this classification with others found in the literature. Firstly, we compared the internal and external variance of the groups.

\footnotetext{
2 We thank one of the anonymous reviewer of the BPSR who highlighted the importance of classifying party size in relation to the specific state in which it is competing.
} 
Table 03. Percentage of political party size by Brazilian state (1998-2014)

\begin{tabular}{lrrr|lrrr}
\hline State & Small & Medium & Large & State & Small & Medium & Large \\
\hline AC & 60.58 & 31.73 & 7.69 & PA & 86.72 & & 13.28 \\
AL & 60.9 & 26.32 & 12.78 & PB & 66.93 & 26.77 & 6.3 \\
AM & 68.75 & 24.22 & 7.03 & PE & 79.17 & & 20.83 \\
AP & 72.27 & & 27.73 & PI & 85.16 & & 14.84 \\
BA & 89.47 & & 10.53 & PR & 67.14 & 20 & 12.86 \\
CE & 89.47 & & 10.53 & RJ & 67.12 & 23.97 & 8.9 \\
DF & 88.89 & & 11.11 & RN & 73.77 & & 26.23 \\
ES & 78.2 & & 21.8 & RO & 65.52 & 23.28 & 11.21 \\
GO & 74.79 & 21.01 & 4.2 & RR & 79.17 & 18.33 & 2.5 \\
MA & 72.59 & 24.44 & 2.96 & RS & 79.53 & & 20.47 \\
MG & 66.9 & 23.24 & 9.86 & SC & 82.81 & & 17.19 \\
MS & 88.46 & & 11.54 & SE & 69.47 & & 30.53 \\
MT & 75.44 & & 24.56 & SP & 81.63 & & 18.37 \\
& & & & TO & 78.51 & & 21.49 \\
\hline
\end{tabular}

Source: Brazilian Superior Electoral Court.

Note: AC (Acre), AL (Alagoas), AM (Amazônia), AP (Amapá), BA (Bahia), CE (Ceará), DF (Distrito Federal), ES (Espirito Santo), GO (Goiás), MA (Maranhão), MG (Minas Gerais), MS (Mato Grosso do Sul), MT (Mato Grosso), PA (Pará), PB (Paraíba), PE (Pernambuco), PI (Piauí), PR (Paraná), RJ (Rio de Janeiro), RN (Rio Grande do Norte), RO (Rondônia), RR (Roraima), RS (Rio Grande do Sul), SC (Santa Catarina), SE (Sergipe), SP (São Paulo), TO (Tocantins).

Table 4 shows the results of an analysis of variance, employing ANOVA33. The classification that we propose (via clusters) has a higher sum of squares for external variance (between groups) and a lower sum of squares for internal variance (within groups). This result ensures the highest F-ratio of the exercise. Together this means that the classification via cluster analysis presents more internally homogenous and more externally diverse groups. Consequently, it maximizes the premise that we had adopted. In addition, the comparison with some other classifications requires a different procedure. The ratio is the number of categories. For this we used a t-test to compare the classification via cluster analysis ${ }^{4}$. Table 05 shows the comparison.

\footnotetext{
3 ANOVA is a technique utilized to compare means of three of more conditions based on their sample variance (TRIOLA, 2011). Hence the technique looks for mean differences between groups. The more different the means, the greater the variance between them will be. The opposite is also true: the less difference existing between the groups, the lower the variance (DANCEY and REIDY, 2006).

${ }^{4}$ In this article we used only those states in which the technique identified the existence of just two groups. To explain: our cluster analysis was undertaken by dividing the database by state. This ensures that the technique is replicated for each state party subsystem.
} 
Table 04. ANOVA of the classifications of small party size

\begin{tabular}{lrrrrrr}
\hline & \multicolumn{2}{c}{ Sum of Squares } & & & & \\
& $\begin{array}{r}\text { Between } \\
\text { groups }\end{array}$ & $\begin{array}{c}\text { Within } \\
\text { groups }\end{array}$ & df & N & F & Sig. \\
\cline { 2 - 8 } Our classification & 39559.832 & 10227.534 & 02 & 1409 & 2721.119 & 0.000 \\
Machado (2012) & 38309.389 & 11477.976 & 02 & 1409 & 2348.032 & 0.000 \\
Assis (1997) & 38829.978 & 10957.388 & 03 & 1409 & 1660.826 & 0.000 \\
\hline
\end{tabular}

Table 05. T-test of small party classifications

\begin{tabular}{lccrr} 
& $\mathrm{F}$ & $\mathrm{T}$ & Difference & Sig. \\
\cline { 2 - 5 } Our classification & 1061.927 & -37.217 & -13.68 & 0.000 \\
Dantas and Praça (2004) & 1594.076 & -32.878 & -8.03 & 0.000 \\
Melo and Ev (2014) & 1819.076 & -35.144 & -9.77 & 0.000 \\
\hline
\end{tabular}

In this text, the F-score represents the variance difference of the groups. Groups with similar variance generate lower F-scores. Hence the classifications generating a lower F-score can be taken to be better. Meanwhile the difference between the means of the groups is represented by the T-score; the greater the difference, the higher the score. In substantive terms, a higher T-score indicates that the mean of the percentage of votes of the groups are more distant. Notably, the classification that we propose (via cluster analysis) possesses the lowest Fscore and highest T-score. In other words, it obtains the most homogenous groups and the highest difference between means.

In sum, both the analysis of variance and the t-test indicate the better fit of the classification realized through cluster analysis. Based on this technique it is possible to form internally more homogenous and externally more distinct groups. Consequently, we can affirm that this is the best path to take when it comes to distinguishing SPs from the others. We continue, therefore, by presenting the main information on the electoral performance of parties by size and Brazilian state as classified by cluster analysis.

Table 06 shows the variation in the percentage of votes by party size in two states: Piauí and Rio de Janeiro. We chose these states taking the coefficient of variation as a reference. We selected the states with the highest and lowest values 
in order to compare the percentage of votes. The table below summarizes this information ${ }^{5}$.

Table 06. Statistics of the percentage of votes by party size by state (1998-2014)

\begin{tabular}{llrrrrrr}
\hline State & Size & $\mathrm{N}$ & Min. & Max. & Mean & D. P. & C. V. \\
\multirow{2}{*}{ PI } & Small & 109 & 0,01 & 9.88 & 1.28 & 2.4 & 187.46 \\
& Large & 19 & 10,62 & 38.46 & 18.99 & 7.05 & 37.12 \\
\multirow{2}{*}{ RJ } & Small & 98 & 0,02 & 3.34 & 0.99 & 0.88 & 89.34 \\
& Medium & 35 & 3,41 & 10.04 & 6.02 & 2.11 & 35.12 \\
& Large & 13 & 10,8 & 18.94 & 14.82 & 2.73 & 18.42 \\
\hline
\end{tabular}

Source: Brazilian Superior Electoral Court.

The mean percentage of votes won by SPs in the state of Piauí is $1.28 \%$, while in Rio de Janeiro the figure is around 1\%. As we can observe, the group of small parties has the largest variation in terms of votes. In Piauí, a small party achieved $9.88 \%$ in one particular election, while in Rio de Janeiro the maximum that a small party managed was 3.34\%. This difference results in part from the party competition in the state. While in Piauí only small and large parties compete, in Rio de Janeiro elections are disputed by small, medium and large parties.

This variation illustrates the difficulty of setting percentage bands of votes to classify parties, the practice commonplace in the literature. The establishment of limits ignores the variation in electoral performance of parties within state subsystems. Cluster analysis overcomes this difficulty and relativizes the intervals of the categories by taking into account the electoral performance of all parties present in the subsystem.

This methodology presents another advantage: it allows the same party to assume different size categories within the distinct subsystems. In a country of continental proportions, it is reasonable to presume that a party can be large in one state and medium or small sized in another. This becomes even truer when we consider the party share of votes in each subsystem. To illustrate this variation, Figure 01 shows the frequency of party size over the period analysed.

\footnotetext{
${ }^{5}$ Data for all states are available as Supplementary data at the BPSR webpage. See: www.bpsr.org.br/files/archives/Dataset_Nascimento.
} 
Figure 01. Size of political parties in Brazil (1998-2014)

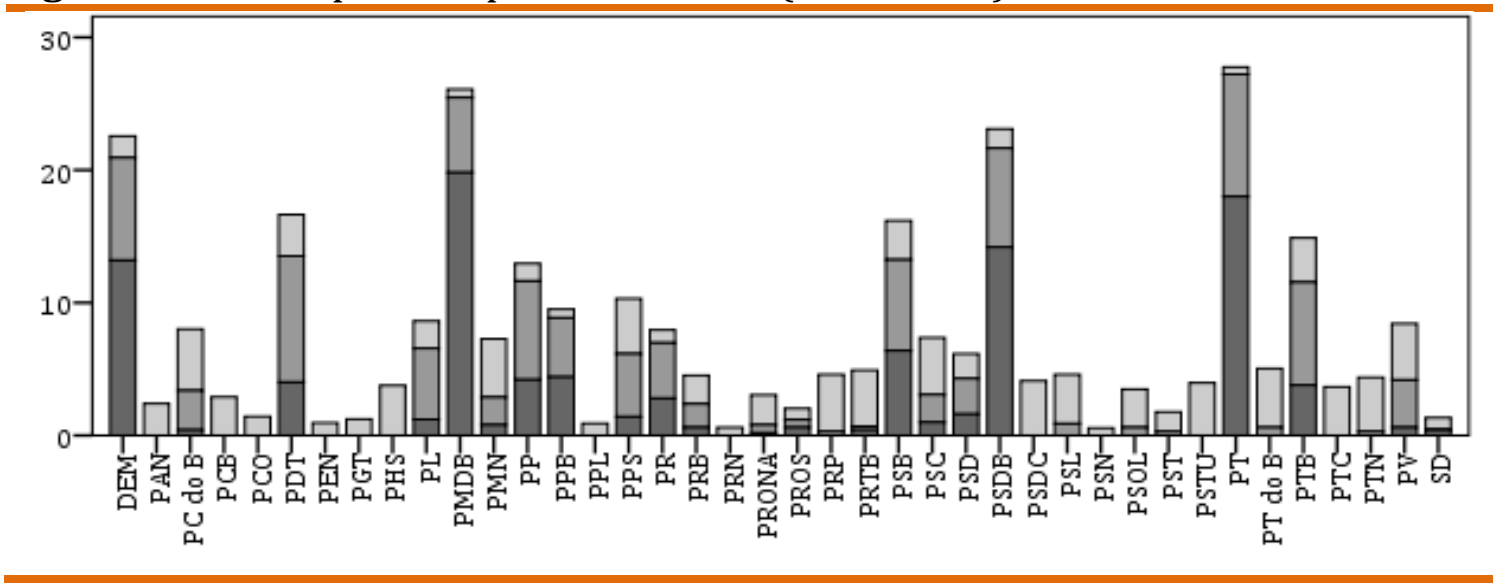

Source: Brazilian Superior Electoral Court.

The figure above shows the size of parties over the five last elections. According to the figure, all parties were considered small at some moment in some state, even those ones commonly considered large, such as PT (Partido dos Trabalhadores), PSDB (Partido da Social Democracia Brasileira) and PMDB (Partido do Movimento Democrático Brasileiro). We emphasize that the percentage (100\%) rounds off for each size group; for example, among all the small parties during the period, DEM (Democratas) corresponded to $2.70 \%$ of them; by contrast, it corresponded to $13.20 \%$ of the large parties. In the composition of small parties, PC do B (Partido Comunista do Brasil) had the highest value (4.63\%), followed by PT do B (Partido Trabalhista do Brasil) 4.44\% - and PMN (Partido da Mobilização Nacional) - 4.41\%.

For space reasons, we cannot replicate this analysis in detail for all political parties. Instead, we prefer to resume our examination of the SPs and analyse the impact of the variation in electoral performance on the number of elected candidates. Figure 02 presents the average of elected candidates of SPs over the last five elections.

The mean of elected candidates of the small parties was 0.25 deputies per state from 1998 to 2014. PMDB obtained a mean of 1.35 elected candidates, followed by PPB (Partido Progressista Brasileiro) with 0.76, PP (Partido Progressista) with 0.71 and the PSDB with 0,69. It is interesting to observe that the SPs with the largest means are large at national level with the exception of PPB. Within the typical small parties PTB (Partido Trabalhista Brasileiro) - 0.54 -, PSB (Partido Socialista Brasileiro) - 0.40 -, PC do B - 0.37 - are among those parties 
above the mean. However, it can be observed that the mean number of candidates elected by SPs is extremely low.

Figure 02. Mean of elected candidates of SPs (1998-2014)

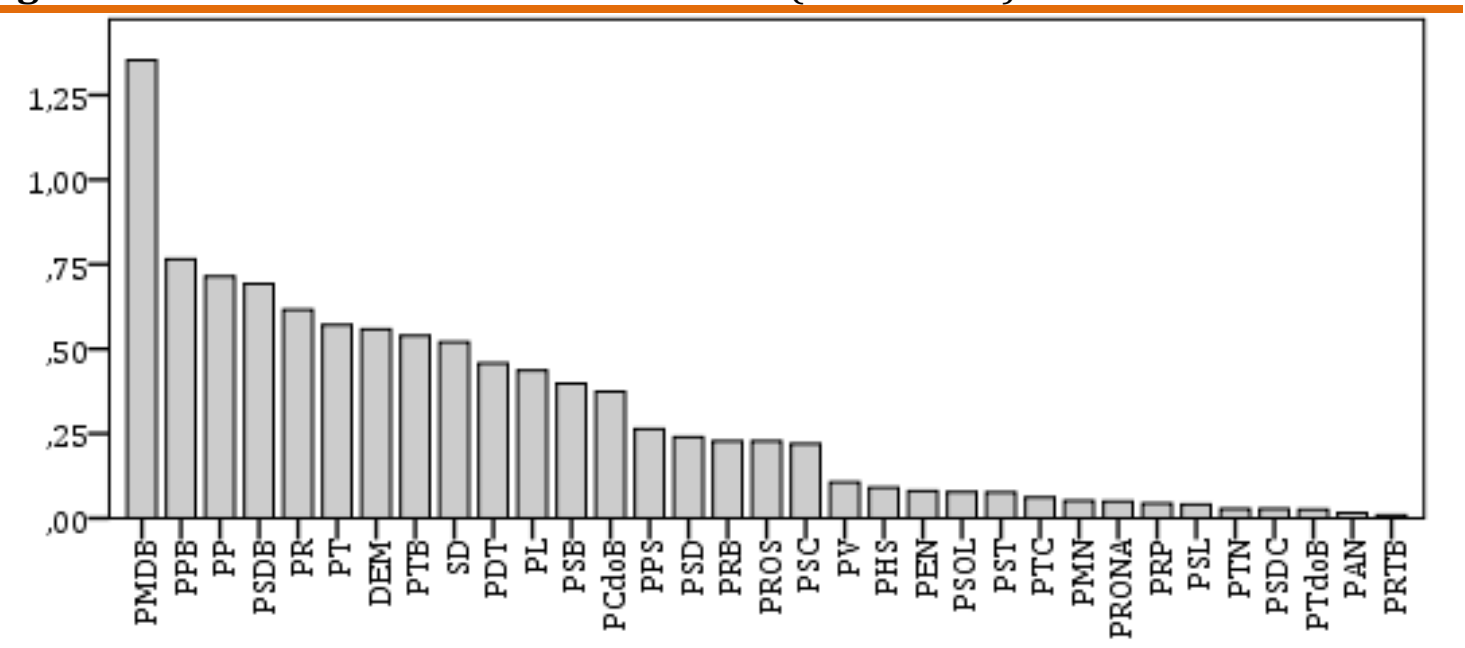

Source: Brazilian Superior Electoral Court.

Note: Parties obtaining a mean equals to 0 were omitted: PSTU, PSN, PRN, PPL, PGT, PCO and PCB.

The electoral results of small parties cannot be analysed without examining their relation to coalitions. In Brazil forming electoral coalitions is one of the main strategies for electoral competition used by political parties, given that allied parties tend to boost their chances of electoral success (CARREIRÃO, 2006; KRAUSE and SCHMITT, 2005; OLIVEIRA, 1973; SOUZA and CAVALCANTE, 2012) ${ }^{6}$. According to the literature (ASSIS, 1997; DANTAS and PRAÇA, 2004, 2010; MACHADO, 2005, 2012; RODRIGUES, 1995), SPs that compete in coalitions have more chances of electing a candidate that those disputing the elections without alliances. Figure 03 illustrates the information on the mean of elected candidates from SPs by type of participation and electoral year.

6 The data indicates that in most cases the small parties tend to compete in coalitions. See Supplementary online data at the BPSR webpage. 
Figure 03. Mean of elected candidates by type of participation and electoral year (IC 95\%)

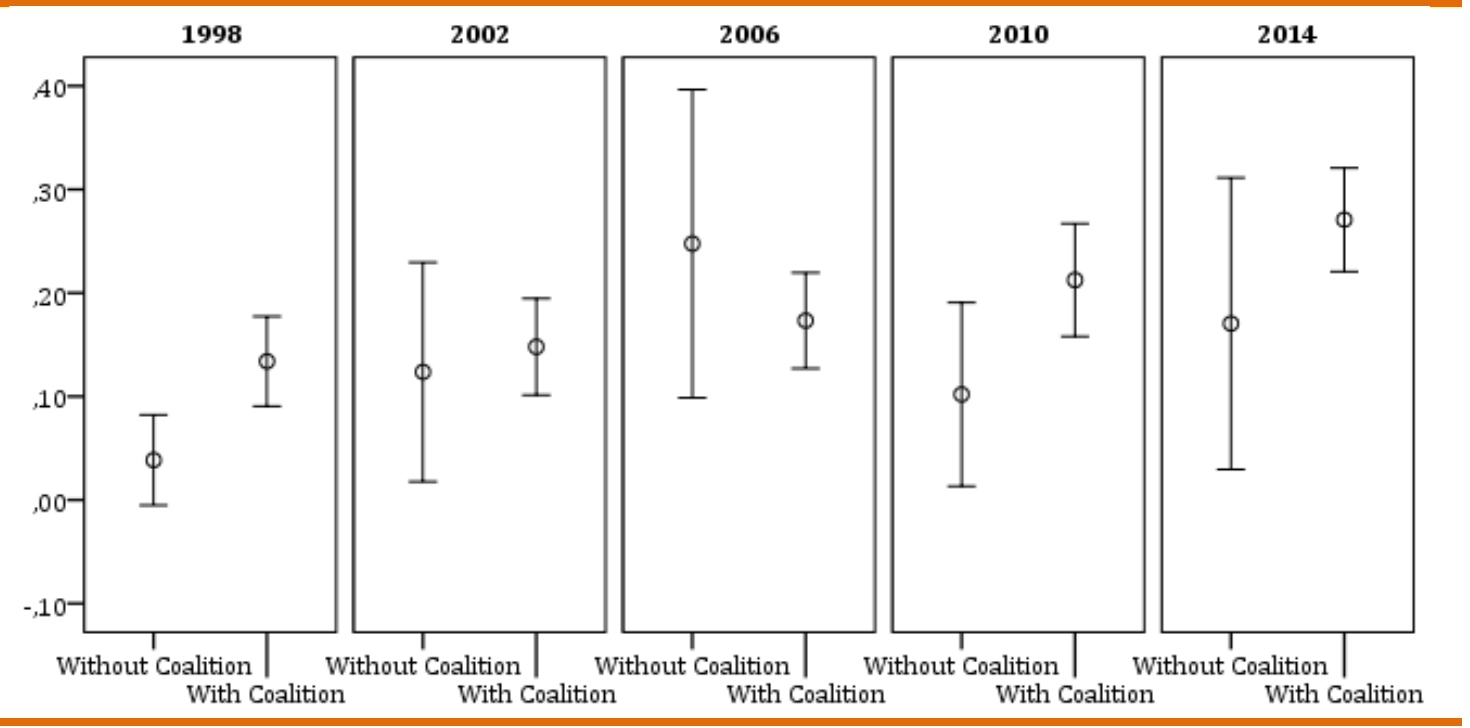

Source: Brazilian Superior Electoral Court.

Note: Coalition here refers to electoral coalition, not to government coalition.

The mean of elected candidates tends to be higher when the small party is in a coalition. The average seats for a coalition party was 0.13 in 1998 and ends the series with 0.27 in 2014. The 2006 elections were atypical since the SPs elected on average more candidates when they competed without any electoral alliance $[0.25$ elected compared to 0.16 elected in a coalition).

In order to finalize the description of the electoral performance of small parties, at an aggregate level, it is important to examine the times series for measures such as: 1) number of parties; 2) percentage of votes; 3) mean of seats won by state; and 4) contribution of parties to coalitions. The objective is to describe the dynamic of SPs by election; more precisely, to observe whether trends or ruptures exist in these time series and whether a future point of the series can be predicted from its immediate past. We shall analyse the series in pairs. The graphs and table below initiate the analysis of the number of small parties and the percentage of votes won. 
Graph 01. Number of small parties and percentage of votes per election
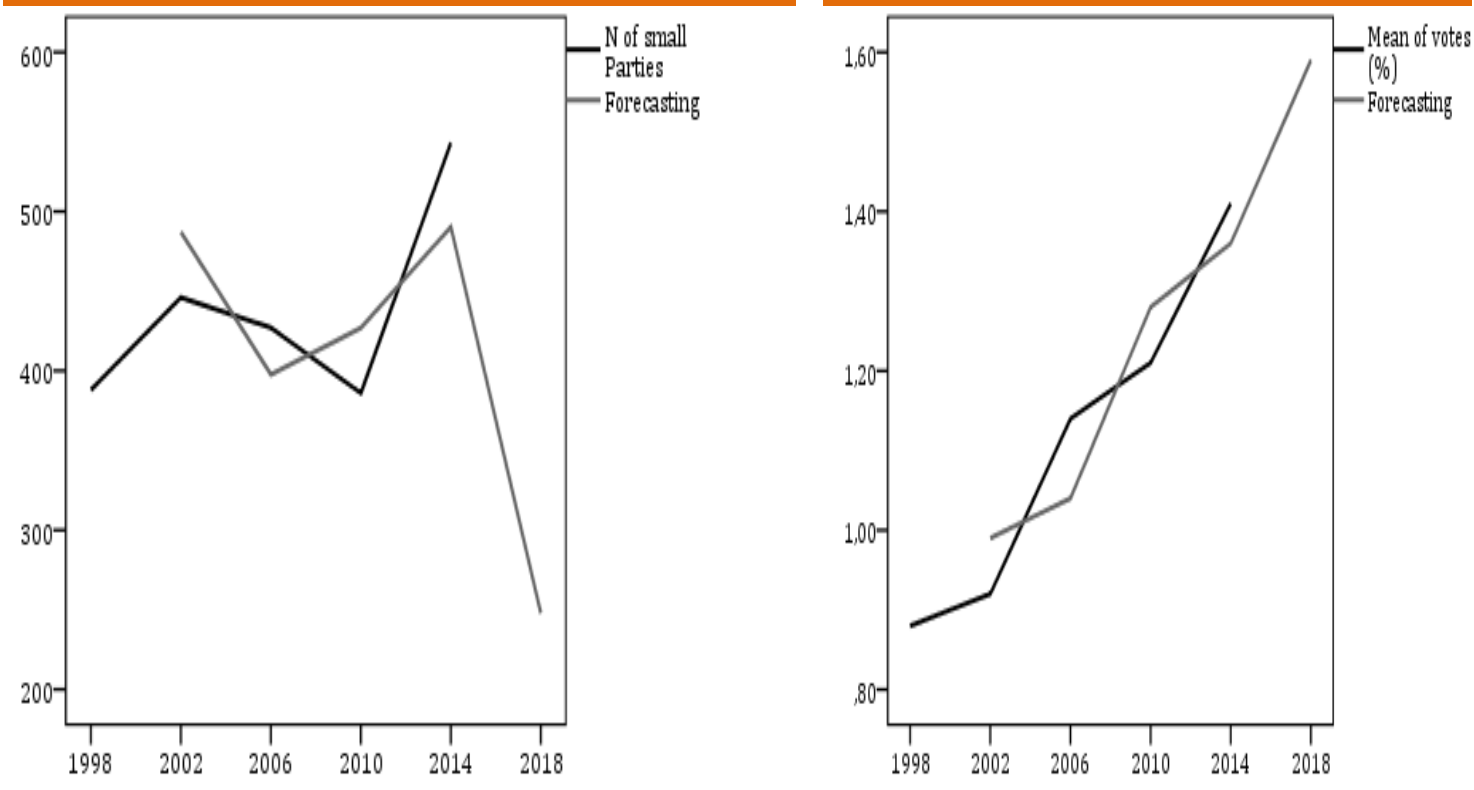

Source: Brazilian Superior Electoral Court.

Table 07. Time series regression models

\begin{tabular}{ccccc}
\hline \multirow{2}{*}{ Measure/Test } & \multicolumn{2}{c}{ Numbers } & \multicolumn{2}{c}{ Percentage } \\
& Values & P-value & Values & P-value \\
\hline KPPS & 0.327 & $>0.100$ & 0.367 & $>0.100$ \\
KPPS* & 0.143 & 0.088 & 0.297 & 0.010 \\
RVQ & 1.640 & 0.998 & 2.228 & 0.998 \\
CHOW & 0.820 & 0.531 & 1.114 & 0.482 \\
Adjusted R2 & 0.207 & - & 0.712 & - \\
F & 1.787 & 0.313 & 8.423 & 0.101 \\
SQR & 7017.219 & - & 0.023 & - \\
\hline
\end{tabular}

Source: Brazilian Superior Electoral Court.

Note: *KPPS including deterministic trend.

In terms of number of parties, the analysis reveals the absence of any trend or rupture in the series. The prediction made for the first lag presents a low fit model (Adjusted R2 $=0.207)^{7}$. This is also reflected in the sum of residuals $(S Q R=$ 7017.219). In conjunction, this result points to the low quality of the predictions. At any rate, the future point indicates a strong fall in the number of parties; if confirmed, the next elections would have the lowest number of SPs of the whole series (248), a reduction of $54.32 \%^{8}$. As for the percentage of votes, the tests merely indicate to the possibility of a deterministic trend existing. The prediction

\footnotetext{
${ }^{7}$ For a deep analysis of the statistics and strength of the coefficient, see Dancey and Reidy (2006), Hair et al. (2009), Kennedy (2009) and Triola (2011).

8 Taking the last election held as a reference point.
} 
for the first lag estimates a moderate fit model (Adjusted R2 $=0.712$ ); compared to the previous model, the sum of residuals is lower (-99.99\%). The future point points to the growth in the mean electoral performance of SPs $(\bar{X}=1.59)$; if confirmed, the growth will be $12.76 \%$. Next, we present the contribution of SPs to the coalitions and the means of seats won by these parties per election.

Graph 02. Contribution of the SPs to coalitions and seats won by SP per elections
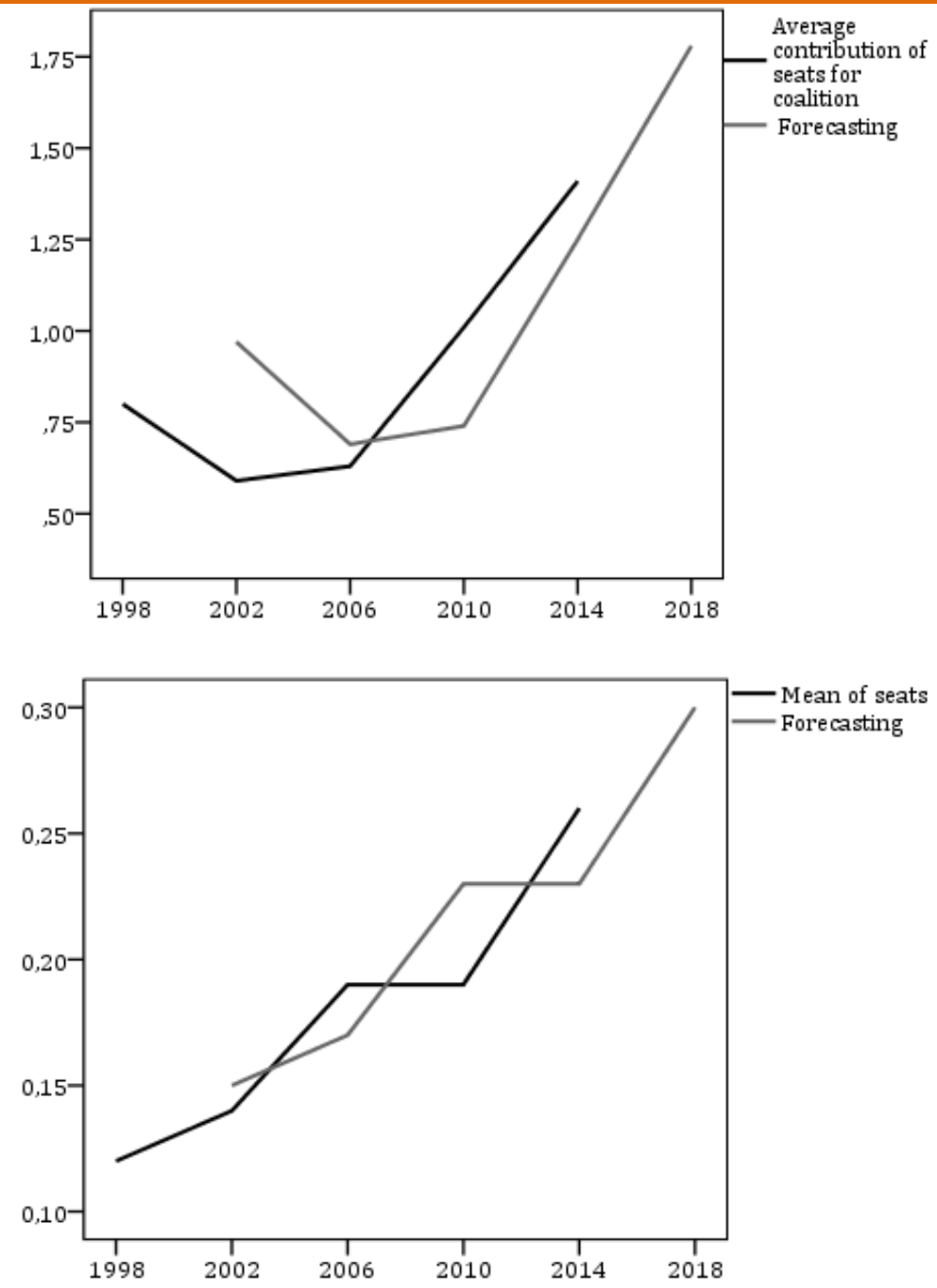

Source: Brazilian Superior Electoral Court.

Graph 02 shows the mean contribution of seats of SPs in coalitions. We compared the effect of withdrawal of the votes of smaller parties on the seats of the coalition. As can be observed, the SPs have been contributing to their coalitions at an increasing rate (0.08 in 1998 and 1.41 in 2014). Graph 02 also shows the mean seats won per state by a SP. Just like the contribution to coalitions, the SPs have been winning an increasing number of seats on average 0.12 in 1998 and 
0.26 in 2014). The table below shows the data on the time series of these two last variables.

Table 08. Time series regression models

\begin{tabular}{lrrrr}
\hline \multirow{2}{*}{ Measure/Test } & \multicolumn{2}{c}{ Contribution } & \multicolumn{2}{c}{ Seats } \\
& Values & P value & Values & P value \\
\hline KPPS & 0.317 & $>0.10$ & 0.382 & $>0.10$ \\
KPPS* & 0.139 & $>0.10$ & 0.255 & $<0.01$ \\
RVQ & 7.569 & 0.454 & - & - \\
CHOW & 3.784 & 0.302 & 0.1748 & 0.748 \\
Adjusted R2 & 0.167 & - & 0.408 & - \\
F & 1.603 & 0.332 & 3.076 & 0.221 \\
SQR & 0.245 & - & 0.003 & - \\
\hline
\end{tabular}

Source: Brazilian Superior Electoral Court.

Note: * KPPS including deterministic trend.

In terms of the contribution of SPs to coalitions, the analysis reveals the absence of a trend or rupture in the series. The prediction made for the first lag presents a low fit model (Adjusted R2 $=0.167$ ). Nonetheless, the sum of residuals is one of the lowest among the four models ( $S Q R=0,245$ ). The future point indicates a growth in the contribution of the SPs for coalitions; if confirmed, the mean contribution of the SPs in the next elections will increase by $26.24 \%$. In terms of the number of seats won by the SPs, meanwhile, the tests indicate the possibility of a deterministic trend existing. The prediction for the first lag estimates a moderate fit model $(\mathrm{R} 2=0.408)$; compared to all the models of previous time series, this has a lower sum of residuals (0.003). The future point indicates a growth in the number of seats won (0.30); if confirmed, the growth will be $15.38 \%$.

In general, the time series indicates a growth in the performance/relevance of small parties ${ }^{9}$. There are no indications of random trends or ruptures. At most, the tests indicate the possible existence of deterministic trends. However, the literature presents no justification for this fact, which suggests that we should regard this outcome with caution. The immediate past better reflects the mean percentage of votes, the number of seats, the number of parties and the contribution.

\footnotetext{
${ }^{9}$ This observation is based solely on the future point predicted by the models. We did not consider the estimated interval, which normally indicates both the reduction and the growth of the measure.
} 


\section{Testing research hypotheses}

In order to answer the main question of this article, we decided to estimate the effect of the SPs on electoral volatility and proportionality. According to the literature, SPs increase volatility and reduce proportionality (BOHN and PAIVA, 2009; KINZO, 2004; KRAUSE et al., 2013; PERES et al., 2011). First, we examined volatility through two strategies: 1) a comparison between the mean electoral volatility of states with a higher and lower number of small parties, and 2) an analysis of the correlation between general volatility (generated by all parties) and the specific volatility of the SPs. Before turning to the tests, it is worth pointing out that the calculation of volatility represents the oscillation in electoral performance of parties in pairs of sequenced elections ( $t$ and $t+1$ ). In the case of the volatility of the SPs, the reference is to the first election; that is, the calculation corresponds to the subtraction of the electoral performance of the parties considered small in the time $t$ from the performance of the same in the following election $(t+1)$, even if they had ceased to be small. Figure 04 presents the comparison between the means for electoral volatility.

The 26 states plus the Federal District were classified in accordance with the number of SPs via cluster analysis ${ }^{10}$. The mean electoral volatility of the states with fewer small parties is higher in three of the four elections analysed (2002, 2010 and 2014). Additionally, in none of them is the difference between means statistically significant. Combined, then, these results indicate the opposite of the hypothesis advanced by the literature. It seems that the higher choice of SPs does not directly alter the electoral volatility recorded in the states.

The analysis of the correlation between the general volatilities and those of the SPs is the second procedure used to test this relation. More precisely, general volatility considers all parties (competitors) present in two consecutive elections. The volatility of the SPs follows the same methodology, limiting only the scope of the parties considered small. Here the objective is to ascertain the extent to which the variance in general volatility can be explained by the volatility of the SPs. Figure 05 summarizes this information.

10 As a measure of similarity we used log-likelihood; the cluster method used was the TwoStep Cluster. The quantity of categories was determined spontaneously by the software. We considered each state in each election as an independent observation. 
Figure 04. Electoral volatility and number of SPs per election (IC 95\%)

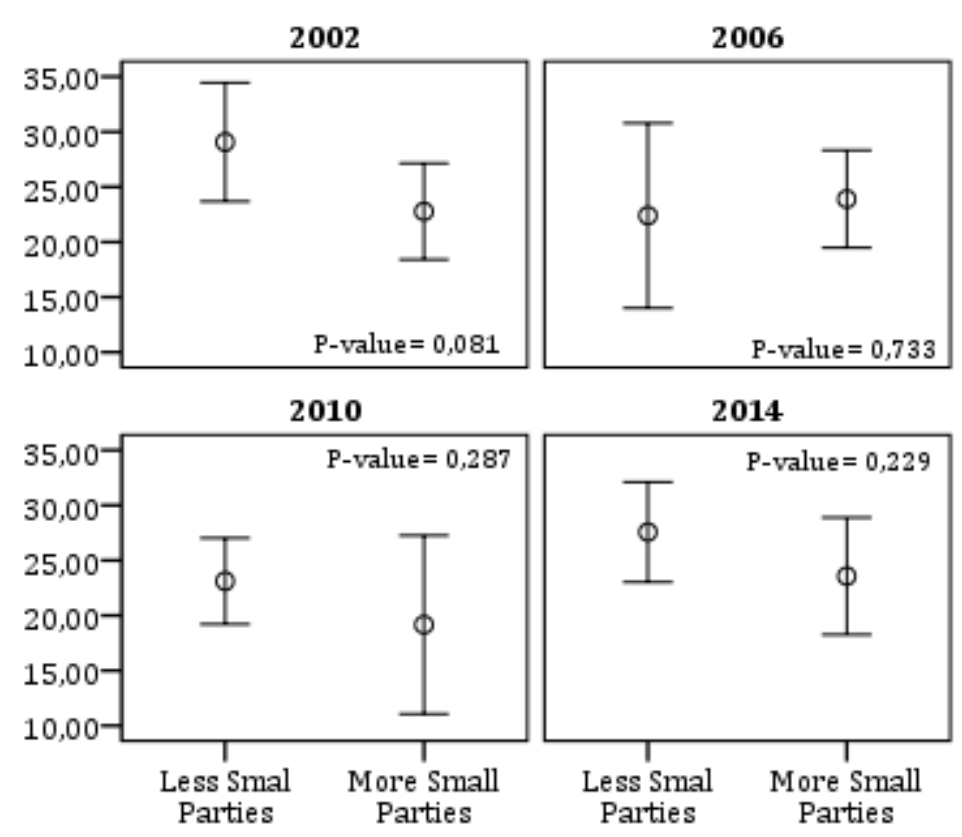

Source: Brazilian Superior Electoral Court.

Figure 05. Regression between electoral volatility of the SPs and total volatility per election

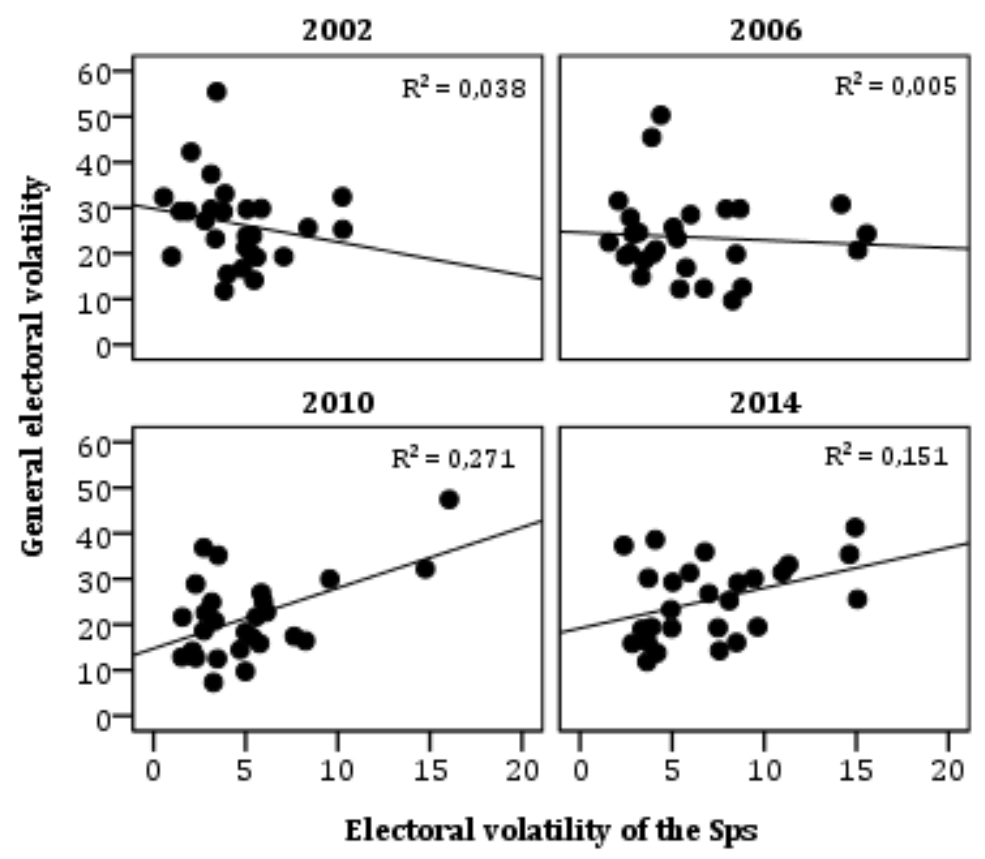

Source: Brazilian Superior Electoral Court.

As the figure indicates, general electoral volatility is little associated with the electoral volatility of the SPs in 2002 and 2006 (R2 of 0.038 and 0.005 respectively); this 
relation increased in 2010 (R2 of 0.271) and decreased in 2014 (R2 of 0.151). In all elections, the correlation between the variables can be considered moderate at most. For example, in the election that recorded the highest correlation (2010), the shared variance is just $27.1 \%$; in other words, $36.4 \%$ of the variance of each variable is independent. This means that most of the variance in overall volatility cannot be attributed to the variance in the volatility of the SPs. Again, this result runs opposite to those predicted in the literature. Combined, the results point to the need to consider the impact of SPs on electoral volatility.

According to the literature, small parties also affect electoral results by increasing the disproportionality of the electoral system. It is also assumed that these parties benefit from this dynamic. We sought to test this argument in two ways: 1) we analysed the association between exceeding the electoral quota and winning seats in the Chamber of Deputies, and 2) comparing the mean disproportionality between a group of parties of different sizes.

In Brazil, coalitions enable a party to elect a candidate without attaining the electoral quota or attaining the quota without electing a single candidate. The two situations represent distortions of proportionality. Part of the literature believes that this dynamic favours some types of political parties, notably the smaller ones. Table 09 summarizes this distortion in relation to the size of the parties.

Table 09. Proportionality by size of party

\begin{tabular}{lllrrr}
\hline & & \multicolumn{3}{c}{ Elected? } & Total \\
& & & No & Yes \\
Small & Exceeded electoral quota? & No & 89.30 & 10.70 & 100.00 \\
& & Yes & 2.70 & 97.30 & 100.00 \\
& Total & & 84.90 & 15.10 & 100.00 \\
\multirow{3}{*}{ Medium } & Exceeded electoral quota? & No & 34.10 & 65.90 & 100.00 \\
& & Yes & 0.00 & 100.00 & 100.00 \\
& Total & & 19.20 & 80.80 & 100.00 \\
\multirow{3}{*}{ Large } & Exceeded electoral quota? & No & 20.90 & 79.10 & 100.00 \\
& & Yes & 0.90 & 99.10 & 100.00 \\
& Total & & 6.00 & 94.00 & 100.00 \\
\hline
\end{tabular}

Source: Brazilian Superior Electoral Court.

Note: Small: $\mathrm{N}=2190 ; x^{2}=615.544 ; \mathrm{p}$-value $=0.000 ; C C=0.468 ; \mathrm{p}$-value $=0.000$.

Medium: $\mathrm{N}=302 ; x^{2}=55.740 ; \mathrm{p}$-value $=0.000 ; C C=0.395 ; \mathrm{p}$-value $=0.000$.

Large: $\mathrm{N}=452 ; x^{2}=60.936 ; \mathrm{p}$-value $=0.000 ; C C=0.345 ; \mathrm{p}$-value $=0.000$. 
From the viewpoint of disproportionality, the frequency of exceeding the quota and non-election are the most-significant crossovers. This is because it tells us who is most negatively affected by disproportionality. According to the table, the small parties benefit less given that $2.70 \%$ of the small parties that exceed the quota failed to elect any candidate. This happened to $0.90 \%$ of the large parties and to none of the medium parties. In sum, disproportionality does not seem to favour SPs, as predicted in the literature. One way of checking and refining these results is to compare the mean disproportionality taking into account the size of parties $^{11}$. Figure 06 illustrates this exercise.

Figure 06. Mean disproportionality of the system by party size (IC 95\%)

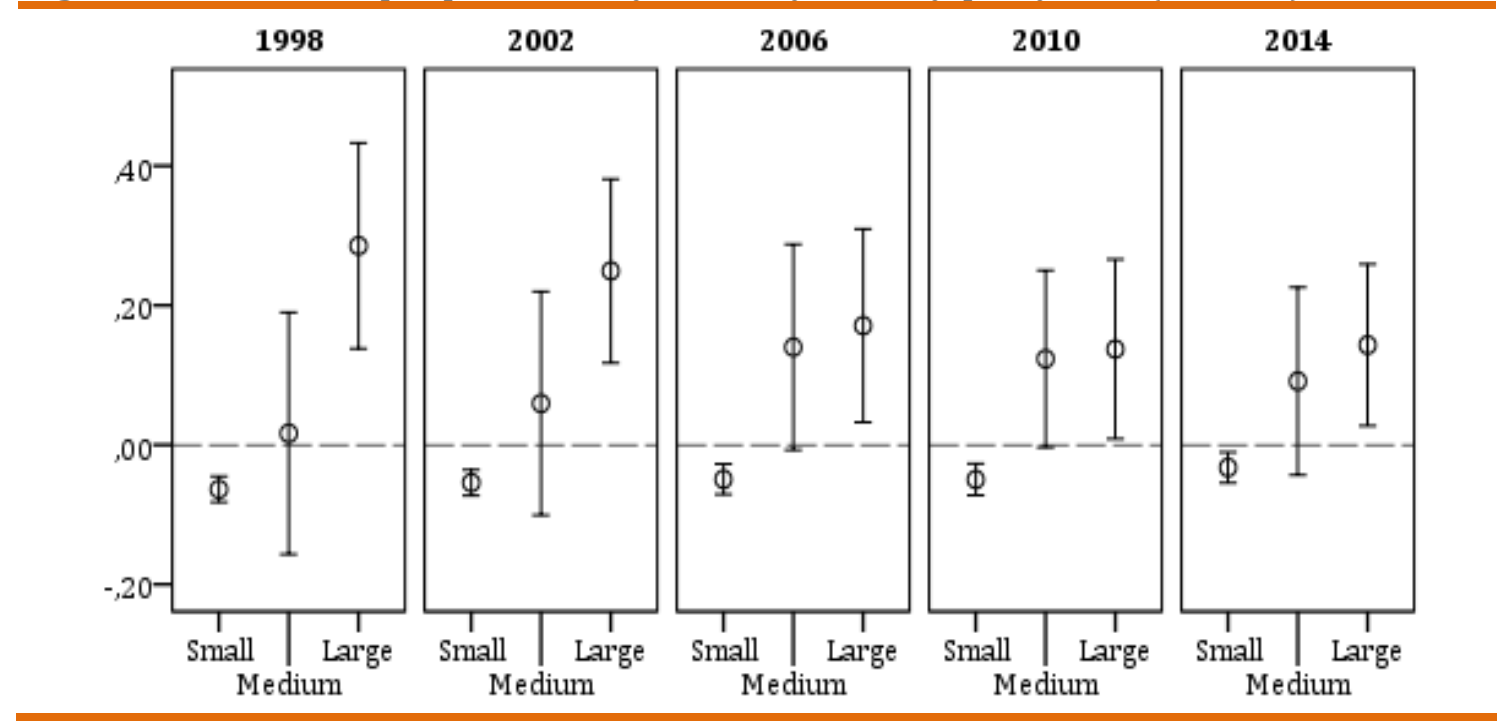

Source: Brazilian Superior Electoral Court.

Here we include just the parties in coalitions. Were the system perfectly proportional, all the means would be on the dotted line (because the difference between the seats with and without coalitions would be 0 ). The number of seats won would be directly proportional to the number of votes won. This is not what happens. Some parties end up benefitting from coalition politics. Irrespective of the election, the parties that most benefit from disproportionality are the medium

11 We calculated the disproportionality as follows: 1) we recalculated the seats that the parties would have the right to contest without coalitions (votes for a party $x$, divided by the electoral quotient); and 2) we subtracted the seats that the parties actually won from the seats that they would have won if the system was perfectly proportional. In sum, our indicator of proportionality is the difference between the seats that the party won through the use of coalitions minus the seats that it would have won through its votes in a perfectly proportional system. 


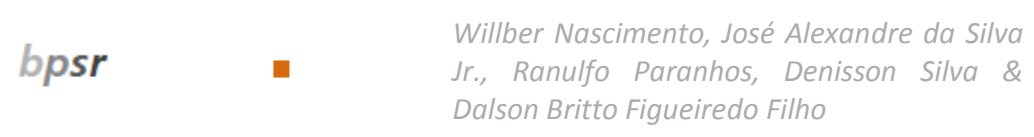

and large ones. On average the small parties are below zero in all elections. This implies that they receive fewer seats than they would win were the system perfectly proportional. The result confirms the previous one: it indicates that the SPs are not the main beneficiaries of electoral party coalitions.

\section{Conclusions}

In this article we analysed the impact and electoral performance of small parties in Brazil in the elections for federal deputy from 1998 to 2014. As for definition, we classify parties in terms of their size through the use of cluster analysis. The first result of this study is that this technique of analysis may represent an advance compared to previous attempts at classification.

As for electoral performance, small parties have generally increased their participation in Brazilian politics, reaching larger portions of the electorate and contributing significantly to their coalitions in terms of votes and seats won. However, these results beyond being proportional to their size do not suggest any trend.

We also analysed the impact of small parties on both electoral volatility and on the proportionality of the system. The results suggest that electoral volatility has been little affected by the increasing of small parties and by their particular volatility. From the viewpoint of proportionality, small parties have a lesser effect than other parties, as well as systematically benefitting less from the disproportionality in coalition politics. These findings run against the observations of the specialized literature on the topic.

Translated by David Rogers Submitted in February 2015 Accepted in September 2015

\section{References}

ALMEIDA, Leânia (2007), Cláusula de barreira: comportamento eleitoral e desempenho partidário nas eleições de 2002 e perspectivas para 2006. Monografia (Especialização). Centro de Formação, Treinamento e Aperfeiçoamento (Cefor) da Câmara dos Deputados. Brasília.

ASSIS, Éder (1997), Goiás: os partidos, as eleições e as transformações recentes. In: O sistema partidário brasileiro: diversidade e tendências 1982-94. Edited by LIMA Jr., Olavo B. Rio de Janeiro: Ed. Fundação Getúlio Vargas. pp. 73-112. 
BOHN, Simone and PAIVA, Denise (2009), A volatilidade eleitoral nos estados: sistema partidário e democracia no Brasil. Revista de Sociologia Política. Vol. 17, № 33, pp. 187-208.

CARREIRÃO, Yan (2012), O sistema partidário brasileiro: um balanço de tendências recentes. Paper delivered at 36ํㅡㄹ Annual Meeting of ANPOCS, Águas de Lindóia. São Paulo.

CARREIRÃO, Yan (2006), Ideologia e partidos políticos: um estudo sobre coligações em Santa Catarina. Opinião Pública. Vol. 12, № 01, pp. 136-163.

DANCEY, Christine and REIDY, John (2006), Estatística sem matemática para psicologia usando SPSS para Windows. Porto Alegre: Artmed. 608pp.

DANTAS, Humberto and PRAÇA, Sérgio (2010), Pequenos partidos no Brasil: uma análise do posicionamento ideológico com base nas coligações municipais de 2000 a 2008. In: Coligações partidárias na nova democracia brasileira: perfis e tendências. Edited by KRAUSE, Silvia; DANTAS, Humberto, and MIGUEL, Luis. Rio de Janeiro: Konrad-Adenauer-Stiftung. São Paulo: Ed. ENESP. pp. 99-133.

DANTAS, Humberto and PRAÇA, Sérgio (2004), Os pequenos partidos nas coligações eleitorais para prefeituras em 2000. Leviathan. № 01, pp. 181-200.

DOWNS, Anthony (1999), Uma teoria econômica da democracia. São Paulo: EDUSP. $330 \mathrm{pp}$.

FEREJOHN, John (1999), Accountability and authority: toward a theory of political accountability. In: Democracy, accountability and representation. Edited by PRZEWORSKI, Adam; STOKES, Susan C., and MANIN, Bernard. Cambridge: Cambridge University Press. pp. 131-153.

FIGUEIREDO, Argelina and LIMONGI, Fernando (1995), Os partidos políticos na Câmara dos Deputados. DADOS. Vol. 38, № 03, pp. 497-526.

FLEISHER, David (2007), Os partidos políticos. In: Sistema Político Brasileiro: uma introdução. Edited by AVELAR, Lúcia and CINTRA, Antônio. Rio de Janeiro: Konrad Adenauer Stiftung; São Paulo: Editora UNESP. pp. 303-348.

GUGIU, Mihaiela and CENTELLAS, Miguel (2013), The democracy cluster classification index. Political Analysis. Vol. 21, № 03, pp. 334-349.

HAIR, Joseph; BLACK, William C.; BABIN, Barry J., and ANDERSON, Rolph E. (2009), Multivariate data analysis. Upper Saddle River: Pearson Prentice Hall. $816 \mathrm{pp}$.

KENNEDY, Peter (2009), Manual de econometria. Rio de Janeiro: Ed. Elsevier. 624 pp. 


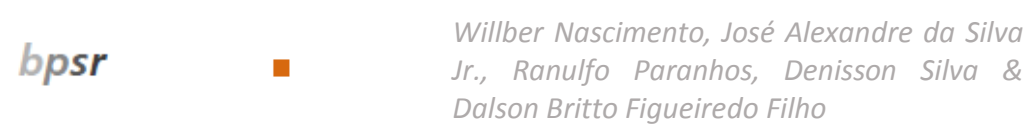

KINZO, Maria (2004), Partidos, eleições e democracia no Brasil pós-1985. Revista Brasileira de Ciências Sociais. Vol. 19, № 54, pp. 23-51.

KRAUSE, Silvana; PAIVA, Denise; RIBEIRO, Pedro, and MELO, Paulo (2013), Fragmentação das eleições locais e a emergência de novas forças políticas no Brasil. Paper delivered at the VII Congreso Latinoamericano de Ciencia Política - ALACIP. Bogotá, Colombia.

KRAUSE, Silvana and SCHMITT, Rogério (orgs) (2005), Partidos e coligações no Brasil. Rio de Janeiro/São Paulo: Konrad-AdenauerStiftung/Editora UNESP. $143 \mathrm{pp}$.

LIMA Jr., Olavo (1983), Partidos políticos brasileiros - 1945 a 1964. Rio de Janeiro: Graal. 157 pp.

LIMONGI, Fernando and CORTÊZ, Rafael (2010), As eleições de 2010 e o quadro partidário. Novos Estudos CEBRAP. № 88, November, pp. 21-37.

MACHADO, Aline (2005), A lógica das coligações no Brasil. In: Partidos e coligações eleitorais no Brasil. Edited by KRAUSE, Silvana and SCHMITT, Rogério. São Paulo, Rio de Janeiro: Editora Fundação Konrad Adenauer and UNESP, pp. 4383.

MACHADO, Aline (2012), Alianças eleitorais: casamento com prazo de validade: o caso das coligações brasileiras. Rio de Janeiro : Elsevier. 136pp.

MAINWARING, Scott (1999), Rethinking party systems in the third wave of democratization: the case of Brazil. Stanford, CA: Stanford University Press. $390 \mathrm{pp}$.

MAINWARING, Scott and TORCAL, Mariano (2005), Teoria e institucionalização dos sistemas partidários após a terceira onda de democratização. Opinião Pública. Vol.11, № 02, pp. 249-286.

MARCHETTI, Vitor (2008), Poder judiciário e competição política no Brasil: uma análise das decisões do TSE e do TSF sobre as regras eleitorais. São Paulo. PhD Dissertation. PUC-SP.

MELO, Carlos (2011), Individualismo e partidarismo em doze estados brasileiros. Revista Brasileira Ciências Sociais. Vol. 26, № 75, pp. 57-91.

MELO, Carlos (2010), Eleições presidenciais, jogos aninhados e sistema partidário no Brasil. Revista Brasileira de Ciência Política. № 04, pp. 13-41.

MELO, Carlos and CÂMARA, Leonardo (2012), Estrutura da competição pela presidência e consolidação do sistema partidário no Brasil. DADOS - Revista de Ciências Sociais. Vol. 55, № 01, pp. 71-117. 
MELO, Paulo Victor Teixeira Pereira; EV, Leonardo da Silveira (2014), De onde vem e como sobrevivem os nanicos? Analise da votação dos pequenos partidos brasileiros.V Seminário Nacional Sociologia \& Política, 2014, Curitiba. Anals of the V Seminário Nacional Sociologia \& Política. Vol. 01, pp. 1-1.

MENEGUELLO, Rachel (1998), Partidos e governos no Brasil contemporâneo (1985 - 1997). São Paulo: Paz e Terra. 205 pp.

NICOLAU, Jairo (2006), 0 sistema eleitoral de lista aberta no Brasil. DADOS Revista de Ciências Sociais. Vol. 49, № 04, pp. 689-720.

NOVAES, Carlos (1996), Dinâmica institucional da representação? Individualismo e partidos na Câmara dos Deputados. Novos Estudos Cebrap. № 38, pp. 99-147.

OLIVEIRA, Isabel (1973), Notas sobre o comportamento das coligações eleitorais no Brasil (1950-1962). DADOS - Revista de Ciências Sociais. Vol. 10, № 04, pp. 166-183.

PERES, Paulo; RICCI, Paolo, and RENNÓ, Lúcio (2011), A variação da volatilidade eleitoral no Brasil: um teste das explicações políticas, econômicas e sociais. Latin American Research Review. Vol. 46, № 03, pp. 46-68.

RABAT, Nuno (2012), Impacto das propostas da comissão de reforma política sobre os pequenos partidos. Nota Técnica. Câmara dos Deputados, Brasília, DF.

RODRIGUES, Leôncio (1995), Eleições, fragmentação partidária e governabilidade. Novos Estudos CEBRAP. № 41, March, pp. 78-90.

SCHUMPETER, Joseph (1952), Capitalism, socialism, and democracy. London: Allen \& Unwin. 431pp.

SOUZA, Carlos and CAVALCANTE, Maria (2012), Padrões geográficos das coligações eleitorais no Brasil: uma análise pela perspectiva ideológica dos partidos políticos - 2002 e 2006. Paper delivered at the 36을 Anual Meeting of ANPOCS, Águas de Lindóia. São Paulo.

TRIOLA, Mario (2011), Introdução à Estatística. Rio de Janeiro: Editora LTC. 696pp. 